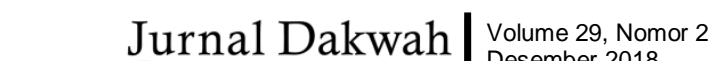 \\ RISALAH \\ P-ISSN: $1412-0348$
}

\section{FENOMENA EKSPLOITASI PEREMPUAN OLEH MEDIA}

\author{
Aslati $^{1}$, Silawati $^{2}$ \\ ${ }^{1}$ Jurusan Pengembangan Masyarakat Islam Fakultas Dakwah dan Komunikasi UIN Suska Riau \\ ${ }^{2}$ Jurusan Bimbingan Konseling Islam Fakultas Dakwah dan Komunikasi UIN Suska Riau \\ Email: aslati@gmail.com
}

\section{Kata kunci}

Eksploitasi;

Perempuan;

Media

\section{Keywords}

Exploitation;

Women;

Media

\begin{abstract}
Abstrak
Setelah Nabi Muhammad SAW lahir dan membawa Risalah Islam Nabi berjuang untuk mengentaskan jurang kehinaan perempuan kepada kedudukan yang mulia dan terhormat. Kehadiran agama Islam menjadi semacam oase yang menyudahi dahaga kaum wanita yang mengharap adanya penetapan hak dan perlakuan yang setara antara laki-laki dan perempuan. Islam datang untuk memberi penghargaan serta penghormatan yang sangat tinggi kepada kaum perempuan. Di sisi lain saat ini perkembangan media massa yang tidak terbendung cenderung melakukan eksploitasi terhadap kaum perempuan. Berbagai media baik cetak maupun elektronik serta media-media online untuk menarik minat khalayak menjadikan perempuan sebagai subjek dan objek paling depan pada media tersebut. Pemberitaan oleh media menjadikan perempuan sebagai daya tarik media itu sendiri. Eksploitasi perempuan oleh media seolah-oleh dijadikan sebagai softpornograpy. Besarnya porsi pemberitaan mengenai seluk beluk perempuan di media seolah-olah membuat laku media tersebut. Kesimpulan bahwa di dalam Islam Perempuan dijaga dengan baik, diperlakukan dengan baik, ditinggikan derajatnya. Sebaliknya kedudukan perempuan dalam media selalu dieksploitasi demi tujuan-tujuan keuntungan baik individu maupun kelompok.
\end{abstract}

\begin{abstract}
After the Prophet Muhammad SAW peace upon him was born and brought the massage of Islam the Prophet struggled to alleviate the abyss of humiliation of women to a position of noble and blessedness. The of Islam is a kind of oasis that quenches thirst for women who expert equal right and treatment between men and women. On the other hand, the current development of unstoppable mass media tends ti exploit women. Various media both print and electronic as well as online mediain attracting the interest of audiences make women the subject and object the front of in the media. Coverage by the media makes women attractive to the media it self. The exploitation of women by the media seems to be used as sofpornograpy. The amount of news coverage about the in and out of women in the media seems to make the media sell well. The conclusion is that in Islam women are well guarded, treated well and exalted. On the contrary, the destruction of women in the media is always exploited for the benefit of individuals or groups.
\end{abstract}




\section{Pendahuluan}

Saat ini perkembangan media massa yang tidak terbendung cenderung melakukan eksploitasi terhadap kaum perempuan. Media seolah-olah berbondong-bondong menjadikan perempuan sebagai objek berita. Jika seorang perempuan melakukan pelanggaran sosial maka pemberitaan tidak akan ada habis-habisnya membahas berita tersebut. Katakanlah yang terbaru terkait berita prostitusi online di kalangan artis. Yang disorot di sini adalah perempuan sebagai subjek berita bahkan secara hukum diproses maka si pelaku prostitusi online tersebut dijadikan sebagai tersangka. Lalu pelaku lakilaki mengapa tidak disentuh sedikitpun oleh media?

Perempuan di arena publik maupun domestik secara umum mengalami subordinasi dan marginalisasi dalam berbagai variasi. Hal ini terkait dengan nilai sosial budaya yang menempatkan perempuan sebagai manusia kelas dua dan lebih rendah dari kaum laki-laki. Berbagai media cetak untuk menarik minat pembaca memasang foto perempuan di sampul media tersebut. Media elektronik seperti televisi membuat iklan untuk memasarkan produk tertentu dengan pemeran perempuan yang sangat dominan. Adanya berita-berita online di media sosial yang menempatkan perempuan sebagai objek pemberitaan seperti terjadinya pemerkosaan maka yang menjadi viral adalah si perempuan, hamil di luar nikah maka yang menjadi objek pemberitaan adalah perempuan, adanya berita perselingkuhan maka yang menjadi objek pemberitaan adalah perempuan.

Pemberitaan oleh media menjadikan perempuan sebagai daya tarik media itu sendiri. Eksploitasi perempuan oleh media seolah-oleh dijadikan sebagai soft pornography. Besarnya porsi pemberitaan mengenai seluk beluk perempuan di media seolah-olah membuat laku media tersebut. Kajian dalam tulisan ini lebih berupa pandangan hipotesis dengan harapan dapat didukung atau diuji secara empiris. Tujuan penulisan ini untuk mengungkap fenomena eksploitasi perempuan oleh media massa di Indonesia.

\section{Metode}

Artikel ini menggunakan studi literatur. Penulis mengumpulkan beragam literatur terkait tema artikel kemudian menganalisisnya sesuai dengan tujuan penulisan.

\section{Pembahasan}

\section{Perempuan dalam Islam}

Dalam perspektif sejarah dapat dibuktikan bagaimana Islam telah mengangkat derajat perempuan hal ini dapat dilihat dengan mengkomparasikan kondisi wanita pra Islam dengan pasca Islam (Muhibbin, 2011). Dari perspektif syariah dapat dibuktikan bahwa hakekatnya tidak ada diskriminasi aantara laki-laki dan wanita dihadapan hokum Islam. Begitu juga dalam perspektif Al-quran bahwa Allah selalu mendudukkan antara laki-laki dan perempuan pada posisi yang sama.

Muhammad Tharir 'Asyur dalam Gunarsa (2012) mengatakan agama Islam sangat memperhatikan kebaikan uurusan wanita, karena wanita adalah setengah dari jenis 
manusia, pendidik pertama dalam pendidikan jiwa sebelum yang lainnya, pendidikan yang berorientasi pada akal agar ia tidak terpengaruh dengan segala pengarug buruk dan juga hati agar tidak dipengaruhi oleh setan.

Pernyataan Nabi SAW ini merupakan peneguhan terhadap dua hal: pertama, bahwa realitas sosial dalam banyak hal sering tidak bersahabat terhadap perempuan dan ini bertentangan dengan misi Islam itu sendiri. Kedua, bahwa pada kondisi seperti itu pemihakan perempuan menjadi suatu keniscayaan sebagai wujud dari perlakuan baik terhadap perempuan menjadi suatu keniscayaan sebagai wujud dari perlakuan baik terhadap perempuan. Persepsi masyarakat mengenai kodrat perempuan dalam beberapa hal harus di luruskan. Pelurusan itu mudah-mudahan termasuk dalam kategori jihad yang paling baik di mata Allah SWT.

Di dalam Islam menjadi perempuan harus dibanggakan, disyukuri dan dirayakan karena merupakan amanah dari Allah SWT yang diberikan kepada seseorang. Setiap amanah dalam kosmologi Islam adalah ujian bagi proses pemilihan siapa yang terbaik dalam memainkan peran dan kiprahnya bagi masyarakat. Allah SWT menegaskan dalam Alquran surat Al-Mulk ayat 2: "Dialah yang menciptakan kematian dan kehidupan untuk menguji kamu, siapa diantara kamu yang paling baik amal perbuatannya". Semua orang diuji dengan amanah yang sama dan kesempatan yang sama tanpa membedakan laki-laki atau perempuan.

Kaidah fikih Islam telah menggariskan beberapa hal yang patut menjadi perhatian serta tuntunan dalam kaitan tersebut. Mulai dari etika pergaulan, berperilaku, berhias diri dan lainnya. Seperti dipaparkan Dr Abdul Qadir Manshur dalam Fiqh al-Mar'ah al Muslimah, setidaknya ada lima hal menjadi penekanan. Satu diantaranya yakni etika berada di luar rumah. Bagi kaum perempuan, dianjurkan untuk tidak mengenakan pakaian ketat sehingga memperlihatkan lekuk tubuh. Juga hendaknya tidak berpakaian dengan bahan kain tipis yang bisa menampakkan kulit tubuhnya.

Ada etika yang patut dijaga seorang perempuan bila bertemu dengan kaum lakilaki. Antara lain dapat menahan pandangannya, menutup seluruh tubuh kecuali wajah dan kedua telapak tangan, tenang dan terhormat dalam gerak gerik, serta serius dan sopan dalam berbicara. Dalam berhias diri ada batasan-batasannya. Menurut Ibnu Abidin, selain harus menutup aurat, maka syarat dibolehkannya seorang perempuan jika keluar rumah yakni tidak mengenakan perhiasan secara berlebihan dan bersolek (Qardhawi, 2007)

Pendapatnya dihargai serta kelemahannya dilindungi, demikian uraian Sayyid Qutb tokoh ulama terkemuka Mesir. Untuk meneguhkan kedudukan itu, tercantumlah surat an Nisaa (Wanita) dalam Alquran. Surat ini khusus membahas segala hal serta aspek terkait dengan kaum perempuan. Pada intinya, kaum perempuan dipandang sebagai bagian penting demi tegaknya agama. Maka, tdak ada yang lebih diharapkan selain tampilnya sosok perempuan yang shalehah dan sanggup menjaga kodrat maupun martabatnya dalam kehidupan sehari-hari.

Bagi kaum perempuan, dianjurkan untuk tidak mengenakan pakaian ketat sehingga memperlihatkan lekuk tubuh. Juga hendaknya tidak berpakaian dengan bahan 
kain tipis yang bisa menampakkan kulit tubuhnya. Yang semacam itu juga dikhawatirkan bisa menimbulkan hal-hal tidak diinginkan. Bagaimana berperilaku di muka umum.

Dalam Al-quran Allah menegaskan, "Katakanlah kepada wanita yang beriman, "Hendaklah mereka menahan pandangannya, dan memelihara kemaluannya, dan janganlah mereka menampakkan perhiasannya kecuali yang (biasa) nampak daripadanya." (QS. Annur: 31), misalnya, bila seorang perempuan bersama-sama dengan seorang lelaki yang bukan muhrimnya di tempat sepi. Hal tersebut tentu tidak dibenarkan dan hukumnya haram. Nabi SAW sangat tidak menyukai perbuatan ini.

Dalam salah satu hadis, beliau menyebutkan bahwa berduaan dengan lelaki asing merupakan perbuatan maksiat. "Tidaklah seorang laki-laki berduaan dengan seorang perempuan kecuali setan menjadi pihak ketiga di antara mereka." (HR. Ahmad dan Attarmizi)

Antara lain dapat menahan pandangannya, menutup seluruh tubuh kecuali wajah dan kedua telapak tangan, tenang dan terhormat dalam gerak gerik, serta serius dan sopan dalam berbicara. Dalam berhias diri ada batasan-batasannya. Menurut Ibnu Abidin, selain harus menutup aurat, maka syarat dibolehkannya seorang perempuan jika keluar rumah yakni tidak mengenakan perhiasan secara berlebihan dan bersolek, karena keadaan seperti itu bisa menyebabkan kaum laki-laki tertarik. Sehingga dalam Al-quran, Allah SWT telah mengingatkan agar kaum perempuan tidak meniru tingkah laku orangorang jahiliah zaman dahulu (Al-Ahzab: 33).

\section{Penjagaan Islam terhadap Perempuan}

Dalam Islam senantiasa menjaga citra baik diri perempuan, seperti ketika keluar rumah Islam menyeru untuk memakai hijab (tabir) demi kepentingan kaum wanita itu dan untuk menjaganya, karena dengan hijab itu bisa dijauhkan segala kejelekan. Sebagaimana Allah SWT menegaskan dalam Al-quran surat An-nur : 31 sebagai berikut:

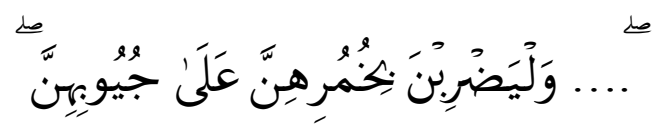

"Hendaklah mereka menahan pandangannya, dan kemaluannya, dan janganlah mereka Menampakkan perhiasannya, kecuali yang (biasa) nampak dari padanya. ...dan hendaklah mereka menutupkan kain kudung kedadanya,..

Islam juga melarang berpakaian yang tidak senonoh karena terdapat bahaya yang jelas atas budi pekerti, sopan santun dan kehormatandiri. Allah SWT menegaskan dalam QS. An-Nur: 30,

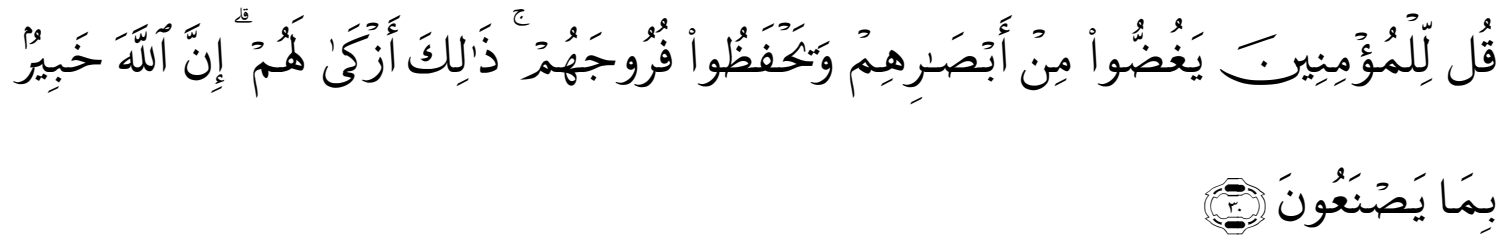


Katakanlah kepada orang laki-laki yang beriman: "Hendaklah mereka menahan pandanganya, dan memelihara kemaluannya; yang demikian itu adalah lebih suci bagi mereka, Sesungguhnya Allah Maha mengetahui apa yang mereka perbuat".

Kemudian Allah SWT menegaskan lagi pada QS. An-Nur: 31,

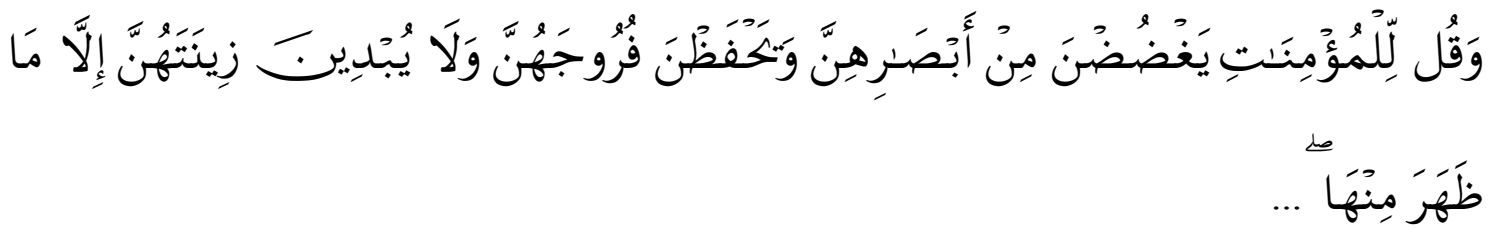

31. Katakanlah kepada wanita yang beriman: "Hendaklah mereka menahan pandangannya, dan kemaluannya, dan janganlah mereka Menampakkan perhiasannya...

Lebih Lanjut Allah SWT tegaskan:

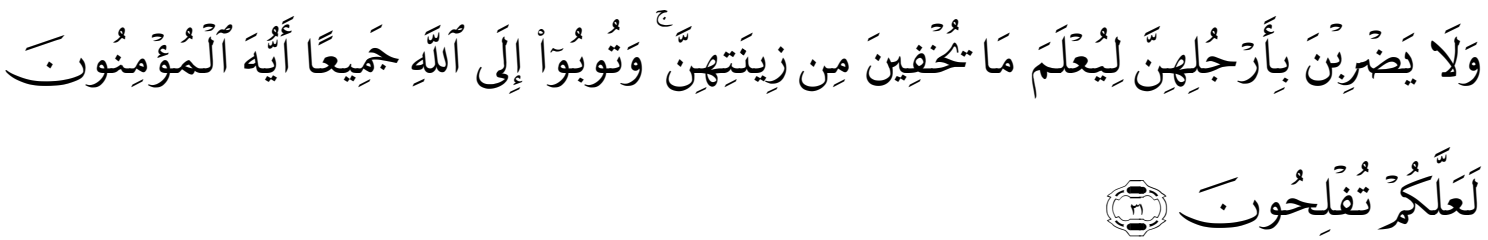

...dan janganlah mereka memukulkan kakinya agar diketahui perhiasan yang mereka sembunyikan. dan bertaubatlah kamu sekalian kepada Allah, Hai orangorang yang beriman supaya kamu beruntung.

Islam melarang perempuan keluar rumah dengan menonjolkan perhiasan tubuhnya agar tidak tersesat di antara orang-orang asing yang bukan muhrimnya. Dengan demikian dapat dipahami hikmah larangan berpakaian yang tidak senonoh. Islam telah menjamin untuk mencegah bahaya syahwat seksuil dengan menetapkan cara ampuh untuk itu baik secara langsung maupun tak langsung.

Abdul Qadir Syaibah dalam Huquq al Mar'ah fi al-Islam mengatakan: "begitulah kemudian dalam undang-undang Islam, wanita dihormati, tidak boleh diwariskan, tidak halal ditahan dengan paksa, kaum laki-laki diperintahkan untuk berbuat baik kepada mereka, para suami dituntut untuk memperlakukan mereka dengan ma'ruf serta sabra dengan akhlak mereka (Gunarsa, 2012).

Selain menjamin hak-hak perempuan, Islam menjaga kaum perempuan dari segala hal yang dapat menodai kehormatannya, menjatuhkan wibawa dan merendahkan martabatnya. Islam menempatkan perempuan sebagai makhluk yang mulia yang harus dijaga. Atas dasar inilah kemudia sejumlah aturan ditetapkan oleh Allah SWT. Perempuan dapat menjalankan peran strategisnya sebagai pendidik umat. Muhammad Thahir Ásyur dalam al-Tahrir wa al-Tanwir berkata; Agama Islam sangat memperhatikan kebaikan urusan perempuan. Bagaimana tidak karena perempuan adalah 
setengah dari jenis manusia, pendidik pertama dalam jiwa sebelum yang lainnya, pendidikan yang berorientasi pada akal agar ia tidak terpengaruh dengan segala pengaruh buruk dan hati agar tidak dirasuki oleh pengaruh setan.

Perempuan diperintahkan oleh Allah SWT untuk menjaga kehormatan mereka di hadapan laki-laki yang bukan suaminya denga cara tidak bercampur baur dengan mereka, lebih banyak tinggal di rumah, menjaga pandangan, tidak memakai wewangian saat keluar rumah, tidak merendahkan suara.

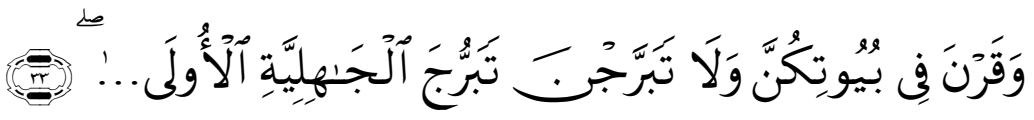

...dan hendaklah kamu tetap di rumahmu dan janganlah kamu berhias dan bertingkah laku seperti orang-orang Jahiliyah yang dahulu...

Semua syariat ini ditetapkan oleh Allah SWT dalam rangka menjaga dan memuliakan kaum Perempuan sekaligus menjamin tatanan kehidupan yang baik dan bersih dari prilaku menyimpang yang muncul akibat hancurnya sekat-sekat pergaulan antara laki-laki dan perempuan. Merebaknya perzinahan dan pelecehan seksual adalah fenomena yang diakibatkan karena kaum perempuan tidak menjaga aturan Allah SWT dan kaum laki-laki lalai dalam menerapkan hukum-hukum Allah SWT atas kaum perempuan.

\section{Fenomena Perempuan di Media}

Perempuan dalam media seringkali digambarkan sebagai objek tatapan pria. Para model yang nyaris telanjang pada sampul majalah pria menjadi hal yang biasa. Para presenter program televisi populer seringkali dipilih berdasarkan wajah dan bukannya berdasarkan bakat yang lebih substansial (Watie, 2010).

Bacalah koran secara acak maka akan dengan mudah menemukan gambar atau berita secara ulasan yang secara gamblang tertang perempuan. Bukalah televisi di rumah anda maka mata akan langsung terbelalak dengan suguhan-suguhan iklan yang didominasi oleh pemeran perempuan. Bukalah media-media online maka yang pertama mata disuguhkan oleh seorang perempuan sedang endors sebuah produk (Marwah Daud Ibrahim dalam Subandi, 1997).

Lihatlah iklan-iklan yang terpampang besar di pinggir-pinggir jalan di perkotaan memajang foto perempuan dengan rambut terurai pakaian yang minim. Bacalah iklan tukang pijat di koran dengan menawarkan ciri-ciri perempuan yang berkulit halus yang menjadi tukang pijatnya. Tentu fenomena ini tak mungkin disebutkan satu persaatu pada paparan ini. Namun dapat dipastikan bahwa semua yang berbau perempuan dieksploitasi habis-habisan oleh media.

Analisis yang dapat diajukan sehubungan dengan pemberian porsi besar pada berita perempuan adalah sebagai alat untuk membuat laku media. Media telah masuk dalam suatu mesin giling kapitalis dan arus konsumerisme. Media telah lumat dalam 
mekanisme pasar yang tidak dapat lagi menghiraukan norma dan etika pergaulan. Bukankah dalam Islam tubuh perempuan tidak boleh diumbar namun justru menjadi komoditas yang mahal nilainya. Perempuan sudah dilihat sebagai benda atau sebagai materi dan tubuh perempuan dilihat sekedar sebagai komuditas.

Pada hakikatnya hubungan perempuan dan media hari ini adalah hubungan yang kompleks dan problematis. Pertama, dalam konteks zaman milenial, seperti ramalan Alfin Tofler, perempuan dalam ranah informasi yang berkembang pesat akibat kemajuan teknologi informasi, hanya menjadi objek pasif dari kepentingan nalar patriarki yang bekerja di belakang media massa. Kedua, perempuan dalam visualisasi media massa, hanyalah alat akumulasi modal berdasarkan stereotipenya sebagai objek hasrat. Ketiga, perempuan dalam pemberitaan-pemberitaan media massa seringkali menjadi korban akibat reportase yang tidak berperspektif perempuan.

Penelitian yang dilakukan PBB tentang peran media dalam perbaikan status perempuan, menunjukkan dua gejala patologis. Pertama, betapa perempuan di berbagai media di dunia dicitrakan hanya berdasarkan stereotipe tinimbang mewakili aspirasi perempuan. Kedua, dalam kaitannya dengan dunia kerja perempuan di institusi media, perempuan hanya terlibat sebatas kerja-kerja administratif belaka dan tidak banyak sampai pada posisi strategis untuk dapat mengambil keputusan-keputusan penting.

Patologi pertama dalam temuan di atas menandakan bahwa ketika perempuan dicitrakan melalui pelbagai wadah dalam kasus ini adalah media, perempuan tidak lepas dan hanya menjadi objek kekerasan simbolik dari suatu cara pandang tertentu. Kedua, melalui cara pandang yang mendiskreditkan perempuan, dalam dunia kerja juga berlaku aturan main yang merepresentasikan pandangan yang menomorduakan perempuan.

Penelitian Nurul Islam melalui Perempuan dalam Media Massa di Indonesia mengemukakan adanya hubungan industri media yang ditopang ideologi kapitalisme dengan perempuan sebagai objek penindasannya. Akibat didorong kepentingan bisnis, perempuan seringkali dijadikan alat bisnis dengan membangun visualisasi sebagai mahluk yang seksi, erotis dan berpenampilan minim demi mengejar profit.

Iklan, sinetron, film, adalah media-media visual yang menurut Nurul Islam adalah tempat perempuan mengalami eksploitasi demi melanggengkan bisnis, produk, ataupun cara pandang, dari pelbagai bentuk tubuh, cara bicara, karakter, dan sifat yang dimiliki perempuan. (Kita sendiri seringkali menyaksikan iklan rokok, mobil, atau pemutih kulit, yang dekat sebagai contoh-contoh yang berkaitan dengan proposisi di atas).

Analasis Michael Foucault, sosiolog berkebangsaan Perancis dalam hal ini telah menerangkan bahwa tubuh merupakan pusat kenikmatan dan sensasi. Artinya tubuh menjadi politis akibat menjadi arena kekuasaan. Dalam konteks kekuasaan kapitalisme melalui industri medianya, tubuh perempuan dikategorisasi dan diidealisasi menjadi bukan sekadar tumpukan daging belaka, melainkan melibatkan penilaian atas dasar seksualitas dan erotisme di dalamnya.

Narasi yang sama juga dikemukakan Yasraf Amir Piliang melalui Dunia yang Dilipat: Tamasya Melampaui Batas-batas Kebudayaan, yakni tubuh dalam kategori economy-politik of the body, telah mengalami semacam "ideologisasi" penandaan yang 
mengaitkan tubuh perempuan dengan penandaan erotis demi melipatgandakan hasrat dalam sistem kerja akumulasi modalnya.

Perempuan yang distereotipekan negatif juga tidak hanya berlaku dalam media elektronik. Melalui Wajah Perempuan dalam Media Massa, Nurul Arifin menuliskan pelabelan-pelabelan negatif terhadap perempuan selamai ini juga ditemukan dalam media cetak. Jika mengandaikan media massa sebagai reperesentasi cara berpikir budaya patriarki, maka media cetak banyak mengadopsi cara pandang demikian ketika menuliskan perempuan sebagai bahan beritanya. Itu artinya perempuan sebagai suatu konsep dan sekaligus objek, melalui tindak penulisan pemberitaan mengalami diskrimanatif dengan kata-kata yang merendahkan perempuan.

Coba perhatikan judul-judul berita di bawah ini:

1. Tergiur Tubuh Molek, Pria Bejat Tega Nodai Anak Tiri (Kamis, 30 Maret 2017. Sindonews.com)

2. Gadis 17 Tahun di Buleleng Digilir Tiga Pria di Kamar Mandi (Kamis, 6 April 2017. Sindonews.com)

3. Bripda Muthia, Polwan Cantik Jadi Korban Penganiayaan (25 Mei 2016. Liputan6.com)

4. Bikin Iri, Dokter Gigi Cantik Ini Usianya Sudah Hampir 50 Tahun! (Selasa, 4 April 2017. Vemale.com)

5. Ingat Syekh Puji? Siapa Sangka Begini Kehidupannya Sekarang Bersama Istri Mudanya (Minggu, 16 April 2017. Tribuntimur.com)

Judul nomor 1, 3, dan 4 dengan terang merupakan judul yang bombastis, tidak berkeadilan gender, dan mengesankan mengobjektifasi perempuan. "Molek", dan "cantik", adalah pilihan kata yang tidak mencerminkan keberpihakan kepada perempuan. "Molek" dan "cantik" secara fungsional sengaja dipakai agar menarik secara konotatif imajinasi hasrat pembaca, terutama pembaca laki-laki. Dikatakan tidak berkeadilan gender dan tidak berpihak kepada perempuan karena di situ perempuan mengalami kekerasan dua kali lipat. Selain dia korban tindakan diskrimantif seperti yang diberitakan, juga mengalami objek kekerasan bahasa yang menjadikannya objek hasrat dari kata-kata yang merendahkan.

Sementara nomor 2 dan 5 adalah judul yang mencerminkan perempuan sebagai barang/ benda yang bisa "digunakan" semaunya. Apabila ditelisik, di balik dua judul ini mewakili ideologi patriarki yang "membendakan" perempuan. Perempuan yang dijadikan benda sama halnya dilucutinya perempuan dari aspek-aspek manusiawinya yang khas perempuan. Bahkan dalam judul nomor 5, nampak sekali makna eksploitatif terhadap perempuan dengan mencantumkan "istri muda" sebagai diksi yang mencerminkan perempuan sebagai objek hasrat.

Citra perempuan di media yang menampilkan wajah dan bentuk tubuh merupakan daya tarik yang tersirat bahwa perempuan sebagai simbol seks. Sosok perempuan dalam media seperti itu menunjukkan stereotipe yang merugikan kaum perempuan itu sendiri. Dalam kondisi ini tanpa disadari sesungguhnya perempuan itu telah dikonstruksi secara social sebagai makhluk marjinal yang dijadikan objek dan komoditas oleh media. 
Iklan-iklan yang menampilkan perempuan sudah mendiskriminasi perempuan melalui visual dan teks-teks tertentu. Katakanlah sebait iklan jasa pijat di salah satu media cetak yang berbunyi: "Menerima jasa pijat, dengan tenaga profesional, kulit putih mulus". Pertanyaannya, mengapa tenaga yang memberi jasa pijat disebutkan berkulit putih, mulus. Tersirat pesan di sini bahwa perempuan yang mempunyai profesi tukang pijat mempunyai kulit putih, mulus adalah sebagai daya tarik pelanggan. Dapat dipastikan di sini bahwa yang akan bergairah membaca iklan jasa pijat ini adalah kaum laki-laki. Disinilah Nampak peran media yang mengeksploitasi kaum perempuan dimana elemen seksualitas ditonjolkan ketika ia menjadi pembawa pesan. Di media juga, perempuan dan tubuhnya digunakan dalam berbagai aktivitas ekonomi berdasarkan konstruksi social. Menampilkan tubuh perempuan semata-mata karena tubuh perempuan merupakan nilai jual bagi produk tertentu.

Tidak saja melalui bahasa, perempuan seringkali mengalami pelecehan, diskriminasi, dan kekerasan melalui simbol-simbol. Mulai dari iklan, film, sinetron, talkshow, hingga gambar pendukung dari sebuah berita, perempuan sering menjadi penanda simbolik demi tujuan-tujuan tertentu. Tubuh perempuan yang kebanyakan sering dijadikan "alat" pendongkrak, dalam hal ini seperti yang dinyatakan dalam objetification theory oleh Fredrickson dan Roberts adalah "...that women exist in a culture which their bodies are "looked at, evaluated, and always potentially objectified".

Cobalah simak tampilan iklan di media belakaangan ini baik elektronuk, cetak, online, selain dipenuhi gaya pria perlente, juga bertaburan dengan aksi perempuan ayu dan seksi, namun kesan yang muncul tetap saja menunjukkan lelakilah yang lebih dominan. Menurut Deddy Mulyana dalam Wibowo (2003) kebanyakan iklan di media massa merupakan reproduksi stereotip peran tradisional kaum perempuan. Pria dan perempuan digambarkan sebgaai dua makhluk yang memiliki dunia yang berbeda. Perempuan digambarkan hanya peduli dengan rumah tangga dan fisik mereka.

\section{Simpulan}

Di akhir tulisan ini penulis menyimpulkan bahwa tanpa usaha yang sistematis perempuan akan terus digambarkan seperti saat ini melalui iklan, film, radio, mediamedia online yang terkesan sebagai warga kelas dua yang hanya mampu mengurus rumah tangga, anak-anak, yang bodoh, tak mampu mengambil keputusan, yang lemah dan merupakan pelayan bagi suami dan keluarga. Selalu diperlakukan sebagai objek yang dipamerkan oleh media. Sebagai objek yang dapat diuraikan sedetil mungkin tentang tubuhnya. Tentu saja harapan penulis bahwa analisis ini dapat menjadi referensi untuk dilakukan penelitian lebih lanjut bagi para akademisi untuk kesempurnaan hasil yang lebih utuh.

\section{Referensi}

Al-Asqalani, Ahmad bin Ali bin Hajar. (1993) Fath al-Bari. Beirut, Lebanon: dar AlFikr. 
Al-Qardhawi, Y. (2007). Perempuan Dalam Pandangan Islam,Mengungkap Persoalan kaum Perempuan di Zaman Modern dari Sudut pandang Syariah, Terj. Dari Kitab asli Markaz al-Mar'ah fi al-Hayah al-Islamiyah, Pentrj. Dadang Sobar Ali. Bandung: Pustaka Setia.

Al-Syawkani, Muhammad nin Alk, Nayl al-Authar Syarh Mintaqa al-Akhbar min Ahadits al Akhyar, Dar al-Fikr.

Husein, M. (2001). Fiqh Perempuan: Refleksi Kyai atas agama dan Gender. Yogyakarta: LKIS

Ibrahim, I.S. (1998). Wanita dan Media: Konstruksi Ideologi Gender dalam Ruang Publik Orbe baru. Bandung: Rosdakarya

Ibrahim, I.S. (Ed) (1997). Ecstasy Gaya Hidup: Kebudayaan Pop Dalam Masyarakat Komoditas Indonesia. Bandung: Mizan.

Islam, N. (2008). Perempuan Dalam Media Massa di Indonesia: Analisis isi media massa tentang sosok perempuan dalam paradigma kritis. Jurnal Studi Gender \& Anak, 3 (1): 89-100

Kodir, F. A. (2004). Bangga Jadi Perempuan. Jakarta: Gramedia Pustaka Utama.

Muhibbin, Z. (2011) Wanita dalam Islam. Jurnal Sosial Humaniora, 4 (2): 109-120

Mulyasih, R. (2016). Pentingnya Literasi Media Bagi Kaum Perempuan. Jurnal Lontar 4 (3).

Prabasmoro, A. P. (2013). Putih, Feminisme dan Seksualitas Perempuan dalam iklan Kita. Jakarta: Yayasan Jurnal Perempuan.

Watie, E.D.S. (2010). Representasi Wanita Dalam Media Massa Masa Kini. Jurnal The Messenger, 2 (2): 1-10.

Wibowo, W. (2003). Sihir Iklan: Format Komunikasi Mondial Dalam Kehidupan Urban-Kosmopolit. Jakarta: Gramedia 